\title{
The são Francisco river (NE): review on the interannual loading of particulate matter suspended to the ocean and impacts of dams
}

\begin{abstract}
The order of magnitude of the global transport of materials through the rivers is still a controversial topic. The São Francisco River (NE- Brazil) Midsize (L $=2863 \mathrm{~km}, \mathrm{AB}$ $=640 \mathrm{x} 103 \mathrm{~km} 2)$ is characterized by multiple uses, and a system of dams in cascade. This article is a review of the particulate matter suspended load in the San Francisco river, through synthesizing, grouping and comparing against other tropical rivers. The annual flows of suspended particulate matter ranged from $0.2 \times 106$ t.a- 1 to $7.7 \times 106$ t.a-1 for the hydrological years of 2001 and 2004, respectively. Despite the existing dams system in the São Francisco, there is considerable interannual variability in the suspended particulate material flow. This variability is associated mainly with extreme hydrological events of floods, when the inflows are higher than the storage capacity of dams, generating large flows and large material loads. The São Francisco River presents a lower yield of the suspended particulate matter when compared to other tropical rivers, which can be attributed to its hydrographic basin presenting semi-arid regions. Besides, the retention due to the cascade of dams contributes to the reduced yield.
\end{abstract}

Keywords: Dams, São Francisco River NE Brazil, particulate matter suspended load
Volume 2 Issue 2 - 2018

\author{
Paulo Ricardo Petter Medeiros,' \\ Geórgenes Hilário Cavalcante, ${ }^{2}$ Edmara \\ Ramos Melo, ${ }^{3}$ Nilva Brandini ${ }^{4}$ \\ 'Institute of Geography, Federal University of Alagoas, Brasil \\ ${ }^{2}$ Institute of Atmospheric Sciences, Federal University of \\ Alagoas, Brasil \\ ${ }^{3}$ Institute of Atmospheric Sciences, Federal University of \\ Alagoas, Brasil \\ ${ }^{4}$ Laboratory of Marine Sciences, Federal University of Alagoas, \\ Brasil
}

Correspondence: Paulo Ricardo Petter Medeiros, Institute of Geography, Federal University of Alagoas, Brasil, Email paulopetter_@hotmail.com

Received: November 15, 2017 | Published: April 02, 2018

\section{Introduction}

The transfer of biogenic elements from terrestrial environments to the oceans is a crucial link in global oceanic cycles. ${ }^{1}$ The rivers are the primary transport agents of materials for the coastal region. However, the order of magnitude of this global transport is still a controversial subject. The knowledge level of the contribution of medium and small rivers to the global flow is scarce due to the lack of more consistent local and regional monitoring studies. ${ }^{2,3}$ Current global estimates result from models and extrapolations, such as Meybeck ${ }^{4} \&$ Smith et al..$^{5}$ emphasizing the need for local and regional studies to better estimate nutrient fluxes and suspended particulate matter. The São Francisco River, considered one of the medium sized rivers in the world, represents the most significant drainage basin within Brazilian territory and historically of great socioeconomic importance. Despite the existence of information on the flow during its course since 1936 (www.ana.gov.br) studies on a load of suspended particulate matter and nutrients, are relatively recent and fragmented. This paper makes an interannual review on the suspended particulate matter load of the São Francisco river, synthesizing, grouping and comparing this information with other tropical rivers.

\section{Study area}

The São Francisco River (extension of $2,863 \mathrm{~km}$ and area of the basin $\left(640 \times 10^{3} \mathrm{~m}^{2}\right)$ is divided into four physiographic sectors: Upper, Middle, Sub-Middle and Lower São Francisco (Figure 1). The humid tropical climate of the Köppen Aw type predominates in the Upper Sector; the Aw to BShw types occur in the Middle Sector; the semiarid type BShw in the Sub-Medium Sector, and the type AS, hot and humid, in the Lower Sector. The total annual rainfall in Lower São Francisco ranges from 1,250 to $1,500 \mathrm{~mm}$, the rainy season occurs in the months of May-June-July, with an average yearly temperature of $24^{\circ} \mathrm{C} .{ }^{6}$ According to Ponte ${ }^{7}$ sedimentary geology was recognized by three geomorphological provinces composed of formations of the Cretaceous (mountain ranges), Tertiary (Barreiras Formation) and Quaternary (alluvial and dune) formations. The Corrugated relief zone is related to the pre-Cambrian rocks of the Baixo São Francisco and Sergipe groups, where the lithological differences are responsible for variations in the terrain morphology. Tertiary trays of the Barreiras Formation originate a flat and poorly dissected surface that integrates most of the sediments of the Sub-Medium and Lower São Francisco. The Quaternary Plain consists of deposits of marine, lake and wind origin, which are concentrated in the region of the estuarine delta. The predominant vegetation is the caatinga (scrubland), where the total area of dense, open and degraded caatinga corresponds to $24.6 \%$ in total, the remnants of Atlântica forest (www.ana.gov.br) occur in the basin and coast of the Low San Francisco. In the case of hydroelectric power plants, the main hydroelectric dam is the main anthropogenic impacts of the São Francisco river basin were studied by: Knoppers et al. ${ }^{8}$ \& Medeiros et al..$^{9-12}$

\section{Discussion}

The differential regime of the contribution of the four (4) physiographic sectors of the São Francisco river basin (High, Medium, Sub-Medium and Low) for the total flow is estimated at $42.2 \%, 51.4 \%$, $5.7 \%$ and $0.7 \%$, respectively. ${ }^{13}$ In this way, around $94 \%$ of the total flow of the São Francisco river is generated in the upper and middle São Francisco sectors. However, rainfall occurring in Sub-Middle and Lower São Francisco is vital for water quality, particulate matter flow and nutrients for the estuary and coastal region..$^{10,12,14}$ This importance is due to occur below most of the dam cascade system, generating flows 
that suffer a lower retention of materials. Several climatic phenomena, including El Niño and La Niña, interact at various spatial scales in the drainage basin. ${ }^{15}$ In this way, precipitation anomalies occur in the São Francisco river basin, with periods with lower precipitations and higher than normal climatic conditions. The three annual cycles (2001, 2004 and 2007) exemplify these distinct conditions in the precipitation regime. The year 2001 was characterized by rainfall below normal climatological in all the physiographic sectors of the basin, with critical levels of hydroelectric plant reservoirs. Otherwise, the annual cycles of 2004 and 2007 were characterized by high precipitation, notably in January and February, ${ }^{11}$ causing for the first time, the opening of the spillway gates of the Xingó Hydroelectric Power Plant. Similar to what happened with the precipitations, the flows also presented variations in different hydrological events. According to Medeiros et al. ${ }^{11}$ average monthly flows of the São Francisco River measured at the Xingó Hydroelectric Power Plant, indicate that the average monthly flows of 2001 (excluding January and March) were lower than those occurred in 2004 and 2007. In In terms of average annual flows, the 2001 hydrological year (average of $1496 \mathrm{~m}^{3} / \mathrm{s} \pm 373 \mathrm{~m}^{3} / \mathrm{s}$ ) was lower than in 2004 (average of $1,970 \mathrm{~m}^{3}$ $/ \mathrm{s} \pm 516 \mathrm{~m}^{3} / \mathrm{s}$ ) and this in turn was also lower than 2007 (average of $2,808 \mathrm{~m}^{3} / \mathrm{s} \pm 1,177 \mathrm{~m}^{3} / \mathrm{s}$ ). The flow data for the mouth of the São Francisco River, measured at the Xingó Hydroelectric Power Plant represent the optimization of the operation of the cascade reservoirs for the accumulation of water and electricity production according to the needs of the National Electric System. ${ }^{11}$ Table 1 summarizes the material load of suspended material in the São Francisco River over 7 years of hydrological conditions, comparing the Yield and Yield of the São Francisco river with other tropical rivers. The annual flows of suspended particulate matter ranged from $0.2 \times 10^{6}$ ton. $\mathrm{y}^{-1}$ for the 2001 hydrological year ${ }^{11}$ to $7.7 \times 10^{6}$ ton. $y^{-1}$ in the 2004 hydrological year. ${ }^{11}$ The annual flow of suspended particulate matter in 2004 was higher than the historical value found by Milliman ${ }^{16}$ measured in the period before the construction of the waterfall cascade on the São Francisco River. In 2004, the months of January and February were characterized by peak flows and significant production of suspended particulate matter. High precipitation generated this massive load of suspended particulate matter in the Sub-Medium and Lower São Francisco sectors, from Sobradinho downstream to the Xingó dam, promoting efficient washing, production, and transport of material at the mouth. ${ }^{11}$ These high outflows exceeded the capacity of retention of the reservoirs, forcing the opening of the floodgates of the Xingó Hydroelectric Plant. In February alone, the flow of suspended particulate matter was $6.1 \times 10^{6}$ ton. $\mathrm{y}^{-1}$, with a water flow of $10 \mathrm{~km}^{3}$. Month $^{-1}$, compared to the total annual flow of suspended particulate matter $7.7 \times 10^{6}$ ton. $y^{-1}$ (Table 1). It is interesting to compare the annual flow of suspended particulate matter from the year 2007 of $1.1 \mathrm{x} 106$ ton.y-1, which was much lower than in 2004, although the year 2004 showed a higher annual flow of water $\left(95 \mathrm{~km}^{3}, 16 \mathrm{~km}^{3}\right.$ only in February) compared to the annual flow of water in 2004 $\left(66 \mathrm{~km}^{3}, 10 \mathrm{~km}^{3}\right.$ only in February). According to Medeiros et al. ${ }^{11}$ the geographic location of precipitation is more important in the flow of suspended particulate matter than the magnitude of the precipitation, as well as the flows generated by these precipitations. Precipitations located in the lower portions of the basin, such as those occurring in 2004, are more efficient in the production of materials than those with higher precipitations than located in the upper portions. The results of high flows of suspended particulate matter, occurred in 2004 , corroborate the potential of production and export of materials produced in these sectors. On the other hand, the limitation in this production and the decrease of the load to the coast happens when events of high precipitation occur in the upper portion of the basin since the concentrations of suspended matter are attenuated by the retention and sedimentation along the dam system. ${ }^{11}$ Analyzing data from Santos $^{17}$ for the hydrological year 1983-1984 flow peaks are observed in the first quarter of the year, similar to those found by Medeiros et al. ${ }^{11}$ along with high flows of suspended particulate matter during this period, resulting in an annual flow of $2.1 \times 10^{6}$ ton. $\mathrm{y}^{-1}$. The lowest annual flows of suspended particulate matter, $0.23 \times 10^{6}$ ton. $\mathrm{y}^{-1} .^{9}$ and $0.2 \times 106$ ton. $\mathrm{y}^{-1} .{ }^{11}$ were calculated for the year 2001 and the hydrological year 2000-20001. These values of annual flows of suspended particulate matter and water (Table 1) are quite similar. The limitation in this production and the decrease of the load to the coast happen during periods of low precipitation and flow, generating low production of particulate material in suspension. To maximize the production of hydroelectric energy, the extreme flow management in this period also influenced the flows of suspended particulate matter. ${ }^{9}$ Due to the variability between the inter-annual flows occurring in the São Francisco River, the yields (Y) presented in Table 1, vary from 0.3 ton. $/ \mathrm{km}^{2}$ a1 to 12.1 ton. $/ \mathrm{km}^{2}$. Even the highest values of yields found in the São Francisco river are much lower than in other tropical rivers. In these low-income areas, the fact that the river basin presents large areas of semi-arid climate and also the retention of materials by the cascade dam system ${ }^{11,18}$ influenced these low yields. ${ }^{19-24}$

Figure I The São Francisco River hydrographic basin.

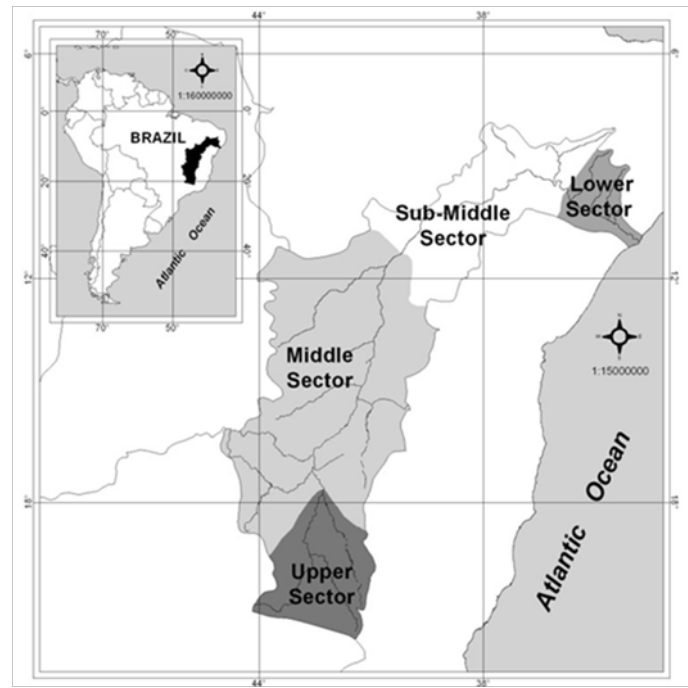

Table I Drainage area, water discharge $(\mathrm{Q})$, sediment discharge $(\mathrm{Q} s)$ and yield (Y) for tropical and subtropical rivers affected by erosion and dam impacts. In parentheses, monthly values of water intake $(\mathrm{km} 3 /$ month) suspended particulate matter (ton. / month) and their yield in the year (ton. / km2.a-I)

\begin{tabular}{|c|c|c|c|c|}
\hline River & $\begin{array}{l}\text { Area }\left(\times 10^{3}\right. \\
\left.\mathrm{km}^{2}\right)\end{array}$ & $Q\left(k^{3} a-{ }^{\prime}\right)$ & $\begin{array}{l}\mathrm{Q}_{\mathrm{s}}\left(10^{6}\right. \\
\text { ton.year' })\end{array}$ & $Y\left(t / k^{2} a^{\prime}\right)$ \\
\hline $\begin{array}{l}\text { São Francisco } \\
1975^{16}\end{array}$ & & 97 & 6,0 & 9,4 \\
\hline São Francisco & & 103 & 2,1 & 3,3 \\
\hline \multicolumn{5}{|l|}{$1983-1984^{17}$} \\
\hline São Francisco & & 71 & 0,4 & 0,7 \\
\hline $1999-2000^{23}$ & 640 & & & \\
\hline São Francisco & & 50 & 0,23 & 0,36 \\
\hline
\end{tabular}


Table Continued

\begin{tabular}{|c|c|c|c|c|}
\hline River & $\begin{array}{l}\text { Area }\left(x \mid 0^{3}\right. \\
\left.\mathbf{k m}^{2}\right)\end{array}$ & $Q\left(\mathbf{k m}^{3} \mathrm{a}-\mathbf{-}^{\prime}\right)$ & $\begin{array}{l}Q_{s}\left(10^{6}\right. \\
\text { ton.year') }\end{array}$ & $\mathbf{Y}\left(\mathbf{t} / \mathbf{k m}^{2} \mathbf{a}^{\prime}\right)$ \\
\hline \multicolumn{5}{|l|}{$2000-200 I^{9}$} \\
\hline \multicolumn{2}{|c|}{ São Francisco 200 I"I } & 47 & 0,2 & 0,3 \\
\hline \multicolumn{2}{|c|}{ São Francisco 2004"I } & 66 & 7,7 & 12,1 \\
\hline \multicolumn{2}{|l|}{ (Fevereiro) } & -10 & $(6, I)$ & $(9,5)$ \\
\hline \multicolumn{2}{|c|}{ São Francisco 2007"I } & 95 & $\mathrm{I}, \mathrm{I}$ & $\mathrm{I}, 7$ \\
\hline \multicolumn{2}{|l|}{ (Fevereiro) } & -16 & $(0,4)$ & $(0,7)$ \\
\hline \multicolumn{2}{|l|}{$\begin{array}{l}\text { Paraíba do } \\
\text { Sul }\end{array}$} & 28 & 0,6 & II \\
\hline \multicolumn{2}{|l|}{ Rio Doce 22,23} & 20 & 9,9 & 110 \\
\hline \multicolumn{2}{|l|}{$\begin{array}{l}\text { Magdalena } 22 \\
\text { (Colombia) }\end{array}$} & 228 & 144 & 560 \\
\hline \multicolumn{5}{|l|}{ Chao } \\
\hline \multicolumn{2}{|l|}{$\begin{array}{l}\text { Phraya }{ }^{24} \\
\text { (Tailândia) }\end{array}$} & 28 & 6 & 37,5 \\
\hline $\begin{array}{l}\mathrm{Fly}^{24} \text { (Nova } \\
\text { Guiné) }\end{array}$ & 75 & & 120 & 61 \\
\hline $\begin{array}{l}\text { Pearl }^{20} \\
\text { (China) }\end{array}$ & 450 & 220 & 40 & 89 \\
\hline
\end{tabular}

\section{Conclusion}

In spite of the existing cascade dam system in the São Francisco River, and the manner in which flows are managed, to maximize the production of hydroelectric energy, there is great interannual variability in the flow of particulate matter in. This variability is associated with extreme hydrological events of floods, when the tributaries are larger than the storage capacity of the dams, generating large defluent flows and material flows. Hydrological events of drought, generate opposite effect, low defluent flows of the Hydroelectric Plant of Xingó and low flow of particulate material in suspension. Precipitations occurring in the lower portions of the basin result in higher streams of suspended particulate matter and dissolved inorganic nutrients, due to the lower retention by the cascade dam system. When compared to other tropical rivers, the São Francisco River presents a lower yield of suspended particulate matter. This is due to large regions of semi-arid climate in the river basin and also by the retention of the dam system. Under normal conditions of precipitation and flow, the flow of suspended material is controlled by the management of the flows through the cascade dam system.

\section{Acknowledgment}

None.

\section{Conflict of interest}

The authors declare no conflict of interest.

\section{References}

1. Ramesh R, Purjava GR, Subramaniun V. Carbon and phosphorus Transport by the major Indian rivers. Journal of Biogeography. 1995;22:409-415.

2. Vörösmarty CJ, Meybeckc M, Feketea B, et al. Anthropogenic sediment retention: major global impact from registered river impoundments. Global and Planetary Change. 2003;39(1-2):169-190.
3. Meybeck M. River basin under anthropocene conditions. In: von Bodungen B, Turner K, editors. Science and Integrated Basin Management. Dahlem workshop series, Wiley. 2001. p. 307-329.

4. Meybeck M. Carbon, Nitrogen and Phosphorus Transport by World Rivers. American journal of Science. 1982;282:401-450.

5. Smith SV, Swaney DP, Talue M, et al. Humans, Hydrology and the distribution of inorganic nutrients loading to the ocean. BioScience. 2003;(53):235-245.

6. Nimer E. Climatologia da Região Nordeste. Revista Brasileira de Geografia. 1972;34(2):3-51.

7. Ponte FC. Estudo Morfoestrutural da Bacia Alagoas-Sergipe. Boletim Técnico da Petrobrás. 1969;12(4):439-474.

8. Knoppers B, Medeiros PRP, Souza WFL, et al. The São Francisco Estuary, Brazil. In: Wangersky P, editor. The Handbook of Environmental Chemistry. Water Pollution: estuaries. Springer. 2006;51-70.

9. Medeiros PRP, Knoppers BA, Santos Junior RC, et al. Aporte fluvial e dispersão da matéria particulada em suspensão na zona costeira do estuário do rio São Francisco (SE/AL). Geochimica Brasiliensis. 2007;21(2):212231 .

10. Medeiros PRP, Knoppers BA, Cavalcante GH, et al. Changes in Nutrients Loads (N,P,Si) in the São Francisco Estuary after the Constructions of Dams. Braz. Arch Biol Technol. 2011a;54(2):387-397.

11. Medeiros PRP, Knoppers B, Souza WFL, et al. Aporte De Material Em Suspensão No Baixo Rio São Francisco (SE/Al), Em Diferentes Condições Hidrológicas. Braz J Aquat Sci Techn. 2011b;15(1):42-53.

12. Medeiros PRP, Santos MM, Cavalcante GH, et al. Inter-annual variability on the water quality in the Lower São Francisco River (NE-Brazil). Acta Limnlogica Brasiliensia. 2016;28(5):1-11.

13. ANA. Disponível. 2008.

14. Medeiros PRP, Santos MM, Cavalcante GH, et al. Características Ambientais do Baixo São Francisco (AL/SE): Efeitos de Barragens no Transporte de Materiais na Interface Continente-Oceano. Geochimica Brasiliensis. 2014;28(1):65-78.

15. Ropelewski CF, Halpert MS. Global and regional scales precipitation associated with El Niño-Southern Oscillation. Mon Weather Ver 1987;115:1606-1626.

16. Milliman JD. A Synthesis. In: Upper continental Sedimentology. Stuttgart. $1975 ; 4: 151-175$

17. Santos CMM. Geoquímica do Carbono e Nitrogênio Orgânico Particulado Transportados Durante Um Ano Hidrológico (1984-1985) Pelo Rio São Francisco, Brasil e Transferidos ao Seu Estuário. Dissertação de Mestrado, Instituto de Geociências Universidade Federal da Bahia; 1993. p. 70.

18. Medeiros PRP, Segundo CGH, Melo MEM. Comportamento da turbidez e material em suspensão em um rio com vazão regularizada por sistema de barragens em cascata: Rio São Francisco (NE, Brasil). Geochimicha Brasiliensis. 2015;29(1):35-44. 
19. Carneiro ME. Origem, transporte e destino de matéria biogênica e hidrocarbonetos no estuário do Rio Paraíba do Sul. Tese de Doutorado. Departamento de Geoquímica, Universidade Federal Fluminense, Niterói. 1988. p.196.

20. Dai SB, Yang SL, Cai AM. Impacts of dams on the sediment flux of the Pearl River, southern China. Catena. 2008;76(1):36-43.

21. Randall GW, Mulla DJ. Nitrate nitrogen in surface waters as influenced by climatic conditions and agricultural practices. $J$ Environ Qual. 2001;(30):337-344
22. Restrepo DJ, Kjervfe B. Water discharge and sediment loads from the western slopes of the Colombian Andes with focus on river San Juan. Journal of Geology. 2001;108(1):17-33.

23. Souza WLF, Knoppers B. Fluxos de água e sedimentos a costa leste do Brasil: relações entre a tipologia e as pressões antrópicas. Geochim. Brasil. 2003;17(1):57-74.

24. Walling DE. Human impact on land-ocean sediment transfer by the world's rivers. Geomorphology. 2006;79(3-4):192-216. 